J. Pijar MIPA, Vol. VI No.2, September : 49 - 55

ISSN 1907-1744

\title{
PROGRAM PEMBELAJARAN FISIKA BERBASIS INKUIRI TERBIMBING TIPE PENYELIDIKAN KELOMPOK UNTUK MENINGKATKAN KEMAMPUAN GENERIK SAINS SISWA
}

\author{
Marzuki $^{1}$ dan Hinduan ${ }^{2}$ \\ ${ }^{1}$ Jurusan Fisika FMIPA Universitas Mataram \\ ${ }^{2}$ Program Studi Pendidikan IPA Sekolah Pascasarjana Universitas Pendidikan Indonesia
}

\begin{abstract}
Abstrak : Penelitian ini bertujuan untuk mendeskripsikan kemampuan generik sains (KGS) siswa, menguji apakah KGS siswa mengalami peningkatan yang signifikan melalui pembelajaran dengan Program Pembelajaran Fisika berbasis IT2PK, dan menyelidiki apakah pembelajaran fisika berbasis IT2PK lebih efektif dari pembelajaran reguler dalam meningkatkan KGS siswa. Penelitian ini merupakan penelitian eksperimen kuasi dengan kelompok kontrol tidak ekivalen dan disertai pemberian tes awal dan tes akhir (nonequivalent pretest-posttest control group design). Pembelajaran pada kelompok eksperimen menggunakan pembelajaran fisika berbasis IT2PK, sedangkan pada kelompok kontrol menggunakan pembelajaran reguler. Subyek penelitian ini adalah siswa kelas VII semester 2 tahun ajaran 2008/2009 di sebuah SMP Negeri di Kota Mataram - NTB. Data dikumpulkan dengan tes kemampuan generik sains (KGS) berbentuk tes uraian sebanyak 14 butir, kemudian dianalisis secara deskriptif dan inferensial menggunakan program SPSS versi 16 for Windows. Hasil penelitian menunjukkan bahwa (1) KGS siswa setelah memperoleh pembelajaran berbasis IT2PK secara umum dalam kualifikasi baik, dengan peningkatan skor yang dialami dikategorikan sedang; (2) setelah mendapatkan pembelajaran fisika berbasis IT2PK, KGS siswa kelompok ekperimen mengalami peningkatan yang cukup signifikan; dan (3) pembelajaran fisika berbasis IT2PK lebih efektif dari pembelajaran reguler dalam meningkatkan KGS siswa.
\end{abstract}

Kata kunci : Program pembelajaran fisika, inkuiri terbimbing tipe penyelidikan kelompok, kemampuan generik sains

\begin{abstract}
The aim of this research is to describe the students' generic science skills, to know whether it would have increased significantly after the students underwent learning through the Physics learning program based on guided inquiry with group investigation type or not and to examine whether it is more effective than the Regular Learning Program in improving the students' generic science skills or not. This is a quasi-experimental study in which nonequivalent pretest-posttest control group design is applied. The Physics learning program based on guided inquiry with group investigation type was employed in the experimental group, whereas the Regular Learning Program was employed in the control group. The subjects of this study are the second semester students of class VII in academic year 2008/2009 at a junior high school in Mataram NTB. The data are taken from the students' generic science skills test in a 14 items essay test, and then they are analyzed descriptively and inferentially using SPSS 16 version for Windows. The results showed (1) the description of the students' generic science skills, (2) after learning through the Physics learning program based on guided inquiry with group investigation type, the students' generic science skills increased significantly; and (3) the Physics learning program based on guided inquiry with group investigation type is more effective than the Regular Learning Program in improving the students' generic science skills.
\end{abstract}

Keywords : Physics learning program, guided inquiry with group investigation type, generic science skills

\section{PENDAhULUAN}

Pendidikan IPA khususnya fisika, memiliki potensi yang sangat besar untuk dijadikan sebagai wahana mengembangkan berbagai kemampuan siswa seperti: kemampuan berpikir tingkat tinggi, kemampuan bekerja keras, berbagai keterampilan dasar, sikap jujur, percaya diri, disiplin, serta sikap-sikap positif lainya [1]. Oleh karena itu, kemampuan-kemampuan inilah yang perlu ditumbuh-kembangkan melalui peningkatan berbagai kemampuan dalam pembelajaran Fisika di sekolah. Sehubungan dengan haln itum proses belajar-mengajar (PBM) harus berubah dari "memberi tahu" menjadi "membantu peserta didik agar menjadi tahu" melalui proses inkuiri ilmiah. Melibatkan siswa secara aktif dalam proses inkuiri ilmiah selama pembelajaran merupakan tuntutan dasar dalam pembelajaran fisika.

Kegiatan inkuiri ilmiah oleh siswa dapat dilakukan secara bertahap menurut kemampuan dan jenjang pendidikannya hingga siswa dapat melakukan proses inkuiri dengan lengkap. Pembelajaran inkuiri yang dapat diberikan pada siswa SMP adalah model inkuiri terbimbing (guided inquiry), di mana pada tahap awal pembelajaran guru masih banyak memberikan proses bimbingan, kemudian pada tahap-tahap berikutnya, bimbingan tersebut dikurangi, sehingga siswa mampu melakukan proses inkuiri secara mandiri. Pembelajaran Fisika berbasis inkuiri terbimbing dalam penelitian ini diformat dalam bentuk penyelidikan kelompok (group investigation). Hal ini didasari atas asumsi bahwa siswa lebih mudah mengkonstruksi pemahaman konsep dan kemampuan generik sains jika mereka melakukan sharing dalam belajar [2]. Dengan demikian program pembelajaran yang dikembangkan untuk selanjutnya dinamakan dengan Program Pembelajaran Fisika berbasis Inkuiri Terbimbing Tipe Penyelidikan Kelompok (IT2PK).

Berkaitan dengan berbagai kemampuan yang dapat dikembangkan melalui pembelajaran fisika di sekolah, McDermott [3] mengidentifikasi sejumlah kemampuan dasar yang dapat dikembangkan dalam pembelajaran fisika, yaitu: (1) Kemampuan melakukan 
J. Pijar MIPA, Vol. VI No.2, September : 49 - 55

penalaran baik kualitatif maupun kuantitatif. Siswa hendaknya mampu memecahkan soal-soal yang ada pada buku paket yang direkomendasikan oleh sekolah. Namun demikian, diharapkan siswa tidak hanya memecahkan persoalan secara matematis saja (penalaran kuantitatif), tetapi juga mampu bernalar secara kualitatif. (2) Kemampuan menginterpretasikan representasi ilmiah seperti grafik, gambar, diagram, dan persamaan matematis. Kemampuan ini sangat penting dalam kegiatan ilmiah, mengingat seringkali fakta-fakta/konsep-konsep/ prinsip-prinsip disajikan dalam representasi ilmiah seperti disebutkan di atas, sehingga untuk mengungkap fakta/ konsep/prinsip melalui representasi ilmiah tersebut diperlukan kemampuan interpretasi; (3) Keterampilan proses seperti observasi, menggambarkan kesimpulan, mengidentifikasi asumsi, merumuskan, menguji, dan memodifikasi hipotesis; (4) Kemampuan memecahkan masalah; dan (5) Keterampilan mengemukakan pikiran secara jelas (keterampilan komunikasi). Siswa harus mampu mengkomunikasikan dengan jelas hasil pemikiran mereka, baik secara lisan maupun tertulis. Mengenai kemampuan berkomunikasi, Rutherford [4] menyatakan bahwa komunikasi verbal maupun tertulis begitu penting dalam kehidupan sehari-hari, sehingga guru harus memberikan prioritas yang tinggi pada kemampuan ini.

Reif [5] menyatakan ada sejumlah keterampilan dasar yang perlu dikembangkan dalam pembelajaran fisika, antara lain yaitu: (1) keterampilan menginterpretasi konsep (interpreting), sebagaimana diungkapkan oleh McDermott [3]. (2) Keterampilan menggambarkan pengetahuan secara efektif (describing). Kemampuan ini diartikan sebagai upaya menggambarkan suatu situasi fisika dalam berbagai cara seperti istilah-istilah, konsep, representasi simbolik seperti kata-kata, diagram, grafik, ataupun simbol matematik. (3) Kemampuan untuk menerapkan pengetahuan secara fleksibel.

Selain pendapat-pendapat dari para ahli yang disebutkan di atas, Suprapto [6] juga merumuskan sejumlah kemampuan yang dapat ditumbuhkan dalam pembelajaran fisika yang disebutnya sebagai kemampuan generik. Beberapa diantara kemampuan-kemampuan tersebut yang dapat dikembangkan pada tingkat SMP antara lain:

(1) Pengamatan (observasi). Pengamatan dapat berupa pengamatan secara langsung dan tak langsung. Dalam pengamatan, unsur kecermatan dan ketelitian serta kejujuran merupakan hal yang amat penting. Sifat-sifat atau nilai ini merupakan ciri manusia berkualitas. Sifatsifat ini sangat penting dimiliki oleh setiap manusia Indonesia karena setiap bidang kehidupan mendambakan sifat ini, sehingga perlu ditumbuh-kembangkan melalui pembelajaran fisika (melalui kinerja laboratorium). Aspek pendidikan penting lainnya yang juga terkait dengan pengamatan adalah kesadaran akan batas-batas ketelitian baik dalam hal pengamatan langsung maupun tak langsung, menggunakan peralatan maupun dengan tanpa peralatan. 2) Kesadaran akan skala besaran ( sense of scale). Siswa perlu dilatih untuk memiliki kesadaran akan skala besaran seperti ukuran panjang, luas, volume, skala waktu, ataupun dalam skala jumlah (sense of number). Ada benda yang ukurannya sangat besar (Jagad Raya) ada juga yang sangat kecil (elektron), ada yang jaraknya dekat ada pula yang jauh, ada yang waktunya sedikit ada pula yang lama, dan sebagainya. Pada tingkat SMP, hal ini bisa dilatih melalui keterampilan menentukan skala pada waktu membuat grafik. Namun keterampilan membuat grafik secara implisit sudah termasuk ke dalam kemampuan mendeskripsikan pengetahuan oleh Reif [5]. Jadi, kesadaran skala ini sudah merupakan bagian dari kemampuan mendeskripsikan pengetahuan.

(3) Bahasa simbolik. Tidak semua gejala-gejala alam dapat diungkapkan dengan bahasa sehari-hari, ada kalanya harus diungkapkan secara kuantitatif dalam bentuk bahasa simbolik. Sifat kuantitatif tersebut menyebabkan adanya keperluan untuk menggunakan bahasa yang kuantitatif juga. Dengan pemakaian bahasa simbolik permasalahan dapat menjadi lebih ringkas dan mudah dipahami. Kemampuan ini secara implisit sudah termasuk dalam kemampuan mendeskripsikan pengetahuan sebagaimana diungkapkan oleh Reif [5], sebab menggambarkan pengetahuan adalah mendeskripsikan dengan kata-kata, simbol-simbol, persamaan, fungsi, diagram, grafik, dan lain-lain.

(4) Inferensi logika. Dalam pengembangan aspek proses sains, inferensi logika diartikan sebagai kegiatan menyimpulkan dari data atau premis-premis kepada suatu contoh lain [7].

(5) Pemodelan matematik. Fisika banyak melibatkan rumus-rumus untuk melukiskan hukum-hukum alam. Rumus-rumus tersebut tidak lain adalah suatu model yang diungkapkan secara matematik. Kemampuan membangun model matematik tidak lain adalah kemampuan menggunakan bahasa simbolik, di mana kemampuan ini tidak lain merupakan bagian dari kemampuan mendeskripsikan pengetahuan seperti diungkapkan oleh Reif [5].

(6) Kemampuan membangun konsep. Sebagaimana dikatakan sebelumnya bahwa tidak semua gejala alam dapat dipahami dengan menggunakan bahasa sehari-hari. Untuk itulah perlu dibangun suatu pengertian yang disebut konsep, seperti misalnya konsep kelajuan, kecepatan, percepatan, dan lain-lain. Secara implisit, kemampuan ini sudah termasuk dalam kemampuan menginterpretasikan konsep seperti yang dikemukakan oleh Reif [5].

Melalui topik tentang kinematika gerak lurus dapat diidentifikasi kemampuan-kemampuan apa saja yang dapat dikembangkan [8]. Hal ini dapat dilihat pada Tabel 1 berikut. 
Program Pembelajaran Fisika Berbasis Inkuiri Terbimbing ..... (Marzuki dan Hinduan)

Tabel 1. Identifikasi Kemampuan Generik Sains yang Dapat Dikembangkan Melalui Topik Gerak Lurus

\begin{tabular}{|c|c|c|c|}
\hline Subtopik & Konsep/Prinsip & Uraian & $\begin{array}{c}\text { KGS yang } \\
\text { Teridentifikasi }\end{array}$ \\
\hline \multirow[t]{4}{*}{$\begin{array}{l}\text { Definisi } \\
\text { Gerak } \\
\text { Benda }\end{array}$} & $\begin{array}{l}\text { Titik acuan dan } \\
\text { satuan } \\
\text { Gerak relatif }\end{array}$ & $\begin{array}{l}\text { Melalui percobaan siswa dapat } \\
\text { memahami pentingnya acuan (dan } \\
\text { juga satuan) untuk menyatakan } \\
\text { gerak suatu benda. } \\
\text { Gerak benda bersifat relatif }\end{array}$ & $\begin{array}{l}\text { - Kemampuan } \\
\text { mendeskripsikan } \\
\text { pengetahuan } \\
\text { - Kemampuan inferensi } \\
\text { logika }\end{array}$ \\
\hline & $\begin{array}{l}\text { Jarak tempuh \& } \\
\text { perpindahan }\end{array}$ & $\begin{array}{l}\text { Jarak tempuh dan perpindahan } \\
\text { merupakan dua hal yang berbeda. } \\
\text { Melalui pemberian beberapa } \\
\text { contoh sederhana siswa dapat } \\
\text { memahami perbedaan antar } \\
\text { keduanya }\end{array}$ & $\begin{array}{l}\text { - Kemampuan inferensi } \\
\text { logika } \\
\text { - Kemampuan } \\
\text { mengaplikasikan } \\
\text { fakta/prinsip/ konsep }\end{array}$ \\
\hline & $\begin{array}{l}\text { Kelajuan dan } \\
\text { kecepatan }\end{array}$ & $\begin{array}{l}\text { Merupakan } 2 \text { hal yang berbeda. } \\
\text { Melalui konsep percepatan siswa } \\
\text { dapat memahami keduanya dan } \\
\text { mendeskripsikan dalam rumusan } \\
\text { matematik. } \\
\text { Diperjelas lagi dengan pemberian } \\
\text { beberapa contoh sederhana }\end{array}$ & $\begin{array}{l}\text { - Kemampuan inferensi } \\
\text { logika } \\
\text { - Mendeskripsikan } \\
\text { pengetahuan baik secara } \\
\text { kualitatif maupun } \\
\text { kuantitatif } \\
\text { - Kemampuan } \\
\text { mengaplikasikan } \\
\text { fakta/prinsip/konsep }\end{array}$ \\
\hline & Kecepatan rata-rata & $\begin{array}{l}\text { Dipahami dengan pemberian } \\
\text { permasalahan sederhana }\end{array}$ & $\begin{array}{l}\text { - Kemampuan } \\
\text { mengaplikasikan } \\
\text { fakta/prinsip/konsep }\end{array}$ \\
\hline $\begin{array}{l}\text { Gerak } \\
\text { Lurus } \\
\text { Beraturan } \\
\text { (GLB) }\end{array}$ & Kecepatan tetap & $\begin{array}{l}\text { Melalui pengkajian hasil } \\
\text { percobaan siswa dapat memahami } \\
\text { konsep GLB serta dapat } \\
\text { menggambar grafik hubungan } s-t \\
\text { dan hubungan } v-t \text {, serta } \\
\text { menginterpretasi grafik atau } \\
\text { representasi ilmiah lainnya, dan } \\
\text { mengaplikasi pengetahuannya } \\
\text { dalam beberapa contoh kasus. }\end{array}$ & $\begin{array}{l}\text { - Kemampuan inferensi } \\
\text { logika } \\
\text { - Kemampuan } \\
\text { mendeskripsikan } \\
\text { pengetahuan baik secara } \\
\text { kualitatif maupun } \\
\text { kuantitatif } \\
\text { - Kemampuan } \\
\text { menginterpretasikan } \\
\text { representasi ilmiah. } \\
\text { - Kemampuan menerapkan } \\
\text { fakta/prinsip/konsep. }\end{array}$ \\
\hline $\begin{array}{l}\text { Gerak } \\
\text { Lurus } \\
\text { Berubah } \\
\text { Beraturan } \\
\text { (GLBB) }\end{array}$ & $\begin{array}{l}\text { Percepatan rata- } \\
\text { rata dan Percepatan } \\
\text { tetap }\end{array}$ & $\begin{array}{l}\text { Melalui pengkajian hasil } \\
\text { percobaan siswa dapat memahami } \\
\text { konsep GLBB serta dapat } \\
\text { menggambar grafik hubungan } v-t \\
\text {, hubungan } a \text { - } t \text {, dan hubungan } s-t \text {, } \\
\text { serta menginterpretasi grafik atau } \\
\text { representasi ilmiah lainnya, dan } \\
\text { mengaplikasi pengetahuannya } \\
\text { dalam beberapa contoh } \\
\text { sederhana. }\end{array}$ & $\begin{array}{l}\text { - Kemampuan inferensi } \\
\text { logika } \\
\text { - Kemampuan } \\
\text { mendeskripsikan } \\
\text { pengetahuan } \\
\text { - Kemampuan } \\
\text { menginterpretasikan } \\
\text { representasi ilmiah. } \\
\text { - Kemampuan menerapkan } \\
\text { fakta/prinsip/konsep. }\end{array}$ \\
\hline
\end{tabular}

Permasalahan yang ingin dicari jawabannya melalui penelitian ini meliputi: (1) bagaimanakah deskripsi umum dari kemampuan generik sains siswa setelah mengalami pembelajaran berbasis IT2PK?; (2) apakah kemampuan generik sains siswa mengalami peningkatan yang signifikan setelah belajar dengan pembelajaran fisika berbasis IT2PK?; dan (3) apakah pembelajaran fisika berbasis IT2PK lebih efektif jika dibandingkan dengan pembelajaran reguler dalam meningkatkan kemampuan generik sains siswa?

\section{METODE PENELITIAN}

Penelitian ini merupakan penelitian eksperimen kuasi dengan kelompok kontrol tidak ekivalen dan disertai pemberian tes awal dan tes akhir (nonequivalent pretestposttest control group design). Pada desain ini subyek penelitian tidak dikelompokkan secara acak. Desain ini dipilih mengingat membuat pengelompokan baru di lapangan seringkali tidak dimungkinkan. Adapun rancangan penelitiannya adalah seperti berikut: 
J. Pijar MIPA, Vol. VI No.2, September : 49 - 55

Tabel 2. Rancangan Penelitian Eksperimen Kuasi (Diadaptasi dari Ruseffendi [9])

\begin{tabular}{|l|c|c|c|}
\hline Kelompok & Pretest & Treatment & Posttest \\
\hline $\begin{array}{l}\text { Kelompok } \\
\text { Eksperimen } \\
\text { (KE) }\end{array}$ & $\mathrm{O}$ & $\mathrm{X}_{1}$ & $\mathrm{O}$ \\
\hline $\begin{array}{l}\text { Kelompok } \\
\text { Kontrol (KK) }\end{array}$ & $\mathrm{O}$ & $\mathrm{X}_{2}$ & $\mathrm{O}$ \\
\hline
\end{tabular}

Catatan: $\mathrm{X}_{1}$ adalah pembelajaran untuk kelompok eksperimen (pembelajaran fisika berbasis IT2PK), $\mathrm{X}_{2}$ adalah pembelajaran untuk kelompok kontrol (pembelajaran reguler), serta $\mathrm{O}$ adalah berupa pretes ataupun postes.

Subyek penelitian ini adalah siswa kelas VII semester 2 di sebuah SMP Negeri di kota Mataram- NTB tahun pelajaran 2008/2009. Berikut ini diberikan distribusi sampel penelitian.

Tabel 3. Distribusi Sampel Penelitian

\begin{tabular}{|c|c|c|c|c|}
\hline \multirow[b]{2}{*}{ Kelas } & \multicolumn{2}{|c|}{ Jenis Kelamin } & \multirow[b]{2}{*}{$\begin{array}{l}\text { Jumlah } \\
\text { (Orang) }\end{array}$} & \multirow[b]{2}{*}{ Kelompok } \\
\hline & $\begin{array}{l}\text { Laki-laki } \\
\text { (Orang) }\end{array}$ & $\begin{array}{c}\text { Perempuan } \\
\text { (Orang) }\end{array}$ & & \\
\hline $\mathrm{VII}(\mathrm{C})$ & 19 & 21 & 40 & \multirow{2}{*}{ Eksperimen } \\
\hline VII(I) & 18 & 22 & 40 & \\
\hline VII(D) & 18 & 23 & 41 & \multirow{2}{*}{ Kontrol } \\
\hline VII(H) & 16 & 23 & 39 & \\
\hline Jumlah & 71 & 89 & 160 & - \\
\hline
\end{tabular}

Variabel-variabel penelitian terdiri dari variabel bebas yaitu metode pembelajaran berbasis IT2PK, dan variabel terikat yaitu kemampuan generik sains. Teknik pengumpulan data menggunakan tes kemampuan generik sains dalam bentuk tes uraian sebanyak 14 soal. Perangkat soal ini telah diujicoba sebelumnya dan telah memenuhi persyaratan validitas dan reliabilitas.

Data penelitian dianalisis secara deskriptif dan inferensial. Analisis deskriptif digunakan untuk mendeskripsikan kemampuan generik sains siswa, yaitu dengan mengkonversi rerata skor kemampuan generik sains ke dalam pedoman konversi norma absolut skala lima dengan kategori sangat baik, baik, cukup, kurang, sangat kurang. Sedangkan analisis inferensial digunakan untuk menguji hipotesis penelitian, yaitu menguji perbedaan rerata terhadap skor pretes dan postes dari kedua kelompok siswa ataupun terhadap perbedaan rerata skor n-gain antara siswa kelompok eksperimen dan kelompok kontrol. Sebelum pengujian hipotesis penelitian, terlebih dahulu dilakukan uji persyaratan analisis yang terdiri dari uji normalitas dan homogenitas. Jika kelompok data memenuhi persyaratan analisis, maka digunakan uji statistik parametrik, dan jika sebaliknya digunakan uji statistik non-parametrik. Semua pengolahan data dilakukan dengan menggunakan SPSS versi 16.

\section{HASIL DAN PEMBAHASAN \\ 1. Analisis Deskriptif Hasil Penelitian}

Hasil analisis deskriptif terhadap skor rerata pretes, postes, dan $n$-gain masing-masing kemampuan dari kedua kelompok siswa secara peraspek maupun secara keseluruhan, dapat dilihat pada Tabel 4 berikut ini.

Tabel 4. Hasil Analisis Deskriptif Kemampuan Generik Sains Siswa Kelompok Eksperimen dan Kelompok Kontrol

\begin{tabular}{|c|c|c|c|c|c|c|}
\hline \multirow[b]{2}{*}{$\begin{array}{c}\text { Aspek Kemampuan } \\
\text { Generik Sains (KGS) }\end{array}$} & \multicolumn{3}{|c|}{ Kelompok Eksperimen (KE) } & \multicolumn{3}{|c|}{ Kelompok Kontrol (KK) } \\
\hline & $\begin{array}{c}\text { Rerata } \\
\text { Pretes } \\
\%\end{array}$ & $\begin{array}{c}\text { Rerata } \\
\text { Postes } \\
\%\end{array}$ & $\begin{array}{l}\text { Rerata } \\
\text { N-Gain }\end{array}$ & $\begin{array}{c}\text { Rerata } \\
\text { Pretes } \\
\%\end{array}$ & $\begin{array}{c}\text { Rerata } \\
\text { Postes } \\
\%\end{array}$ & $\begin{array}{l}\text { Rerata } \\
N \text {-Gain }\end{array}$ \\
\hline $\begin{array}{l}\text { Mendeskripsikan } \\
\text { Pengetahuan fisika } \\
\text { secara efektif }\end{array}$ & $\begin{array}{l}10,65 \\
\text { (Sangat } \\
\text { kurang) }\end{array}$ & $\begin{array}{l}70,88 \\
\text { (Baik) }\end{array}$ & $\begin{array}{c}0,67 \\
\text { (Sedang) }\end{array}$ & $\begin{array}{c}10,88 \\
\text { (Sangat } \\
\text { kurang) }\end{array}$ & $\begin{array}{c}35,77 \\
\text { (Kurang) }\end{array}$ & $\begin{array}{c}0,28 \\
\text { (Rendah) }\end{array}$ \\
\hline $\begin{array}{l}\text { Menginterpretasi } \\
\text { konsep atau prinsip } \\
\text { dan representasi ilmiah } \\
\text { lainnya }\end{array}$ & $\begin{array}{l}20,68 \\
\text { (Sangat } \\
\text { kurang) }\end{array}$ & $\begin{array}{l}70,75 \\
\text { (Baik) }\end{array}$ & $\begin{array}{c}0,63 \\
\text { (Sedang) }\end{array}$ & $\begin{array}{l}20,71 \\
\text { (Sangat } \\
\text { kurang) }\end{array}$ & $\begin{array}{c}35,50 \\
\text { (Kurang) }\end{array}$ & $\begin{array}{c}0,18 \\
\text { (Rendah) }\end{array}$ \\
\hline Inferensi logika & $\begin{array}{l}16,30 \\
\text { (Sangat } \\
\text { kurang) }\end{array}$ & $\begin{array}{l}70,10 \\
\text { (Baik) }\end{array}$ & $\begin{array}{c}0,63 \\
\text { (Sedang) }\end{array}$ & $\begin{array}{l}15,30 \\
\text { (Sangat } \\
\text { kurang) }\end{array}$ & $\begin{array}{c}44,00 \\
\text { (Cukup) }\end{array}$ & $\begin{array}{c}0,32 \\
\text { (Sedang) }\end{array}$ \\
\hline $\begin{array}{l}\text { Menerapkan } \\
\text { konsep/prinsip }\end{array}$ & $\begin{array}{c}9,12 \\
\text { (Sangat } \\
\text { kurang) }\end{array}$ & $\begin{array}{l}66,56 \\
\text { (Baik) }\end{array}$ & $\begin{array}{c}0,63 \\
\text { (Sedang) }\end{array}$ & $\begin{array}{c}7,36 \\
\text { (Sangat } \\
\text { kurang) } \\
\end{array}$ & \begin{tabular}{|l|}
21,00 \\
(Sangat \\
kurang) \\
\end{tabular} & $\begin{array}{c}0,15 \\
\text { (Rendah) }\end{array}$ \\
\hline $\begin{array}{l}\text { Kemampuan Generik } \\
\text { Sains (KGS) secara } \\
\text { umum }\end{array}$ & $\begin{array}{c}14,38 \\
\text { (sangat } \\
\text { kurang) }\end{array}$ & $\begin{array}{l}69,39 \\
\text { (baik) }\end{array}$ & $\begin{array}{c}0,64 \\
\text { (sedang) }\end{array}$ & $\begin{array}{l}13,76 \\
\text { (sangat } \\
\text { kurang) }\end{array}$ & $\begin{array}{c}32,08 \\
\text { (kurang) }\end{array}$ & $\begin{array}{c}0,21 \\
\text { (rendah) }\end{array}$ \\
\hline
\end{tabular}

\section{Menguji Signifikansi Peningkatan Kemampuan Generik Sains Siswa Setelah Memperoleh Pembelajaran Fisika Berbasis IT2PK}

Untuk keperluan ini dilakukan uji perbedaan rerata antara skor pretes dan postes KGS pada siswa kelompok eksperimen. Hasilnya seperti pada Tabel 5.

Tabel 5. Hasil Analisis Uji Perbedaan Rerata antara Skor Pretes dan Postes Kemampuan Generik Sains Siswa Kelompok Eksperimen

\begin{tabular}{|c|c|c|c|c|c|}
\hline $\begin{array}{c}\text { Aspek Kemampuan } \\
\text { Generik Sains } \\
\text { (1) }\end{array}$ & $\begin{array}{c}\text { Rerata } \\
\text { Pretes } \\
(\%) \\
(2) \\
\end{array}$ & $\begin{array}{c}\text { Rerata } \\
\text { Postes } \\
(\%) \\
(3) \\
\end{array}$ & $\begin{array}{l}\left|Z_{\text {hitung }}\right| \text { atau } \\
\left|t_{\text {hitung }}\right| \text { dan } p . \\
\text { (4) }\end{array}$ & $\begin{array}{l}\mathrm{Z}_{\text {tabel }} \\
\text { atau } \\
\mathrm{t}_{\text {tabel }} \\
\text { (5) }\end{array}$ & $\begin{array}{r}\text { Ket.*) } \\
\text { (6) }\end{array}$ \\
\hline \begin{tabular}{|l|} 
1. Mendeskripsikan \\
pengetahuan fisika \\
secara efektif
\end{tabular} & 10,65 & 70,88 & $\begin{aligned} \mid Z_{\text {hit }} & =7,786 \\
p & <0,05\end{aligned}$ & $\begin{array}{c}\mathrm{Z}_{\mathrm{ab}} \\
=1,645\end{array}$ & $\mathrm{H}_{\mathrm{o}}$ ditolak \\
\hline $\begin{array}{l}\text { 2. Mengintrpretasikan } \\
\text { konsep atau prinsip } \\
\text { dan representasi } \\
\text { ilmiah }\end{array}$ & 20,68 & 70,75 & $\begin{aligned} \mathrm{t}_{\text {hit }} & =42,325 \\
\mathrm{p} & <0,05\end{aligned}$ & $\begin{array}{l}\mathrm{t}_{\mathrm{tab}}= \\
1,665\end{array}$ & $\mathrm{H}_{\mathrm{o}}$ ditolak \\
\hline 3. Inferensi logika & 16,30 & 70,10 & $\begin{aligned} \mid Z_{\text {hit }} & =7,801 \\
p & <0,05\end{aligned}$ & \begin{tabular}{|c|}
$Z_{\text {tab }}$ \\
$=1,645$ \\
\end{tabular} & $\mathrm{H}_{\mathrm{o}}$ ditolak \\
\hline $\begin{array}{l}\text { 4. Menerapkan } \\
\text { konsep, prinsip, atau } \\
\text { hukum }\end{array}$ & 9,12 & 66,56 & $\begin{aligned} \mid \mathrm{Z}_{\text {hit }} & =7,783 \\
\mathrm{p} & <0,05\end{aligned}$ & $\begin{array}{c}\mathrm{Z}_{\mathrm{ab}} \\
=1,645\end{array}$ & $\mathrm{H}_{0}$ ditolak \\
\hline $\begin{array}{l}\text { Kemampuan generik } \\
\text { sains secara umum }\end{array}$ & 14,38 & 69,39 & $\begin{aligned} \mathrm{t}_{\text {hit }} & =58,833 \\
\mathrm{p} & <0,05\end{aligned}$ & $\begin{array}{l}\mathrm{t}_{\mathrm{tab}}= \\
1,665\end{array}$ & $\mathrm{H}_{0}$ ditolak \\
\hline
\end{tabular}

Catatan *): $\mathrm{H}_{\mathrm{o}}$ ditolak jika $\left|\mathrm{Z}_{\text {hitung }}\right|=1,645$ dan

$$
\left|t_{\text {hitung }}\right|=1,665 \text {, atau } \mathrm{p}=0,05 \text {. }
$$

Tabel 5 di atas memperlihatkan baik pada masing-masing aspek maupun secara keseluruhan menghasilkan nilai $\left|Z_{\text {hitung }}\right|=1,645$ dan $\left|t_{\text {hitung }}\right|=1,665$ Berdasarkan kriteria penolakan $\mathrm{H}_{\mathrm{o}}$ untuk uji perbedaan rerata antara skor pretes dan postes KGS kelompok eksperimen, maka $\mathrm{H}_{\mathrm{o}}$ ditolak pada masing-masing aspek KGS maupun pada kemampuan KGS secara keseluruhan. 
Dengan demikian dapat dikatakan skor KGS siswa kelompok eksperimen sesudah pembelajaran dengan program yang dikembangkan secara signifikan lebih baik dari sebelum pembelajaran. Hal ini menunjukkan Program Pembelajaran Fisika berbasis IT2PK secara signifikan dapat meningkatkan kemampuan generik sains siswa, baik pada masing-masing aspek generik maupun kemampuan generik sains secara keseluruhan. Secara diagram batang dapat ditunjukkan seperti pada Gambar 1.

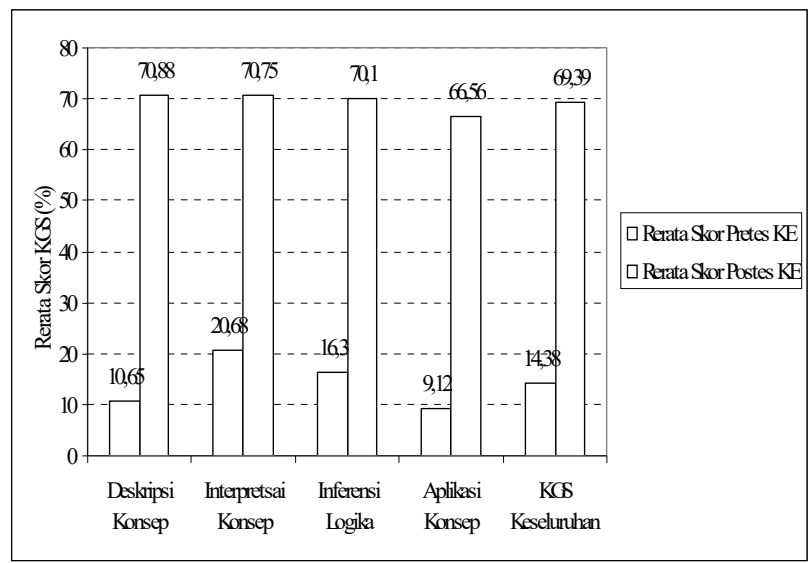

Gambar 1. Perbedaan Rerata antara Skor Pretes dan Postes KGS Siswa Kelompok Eksperimen

\section{Menguji Signifikansi Peningkatan Kemampuan Generik Sains Siswa Melalui Pembelajaran Reguler}

Untuk keperluan ini dilakukan uji perbedaan rerata antara skor pretes dan postes KGS pada siswa kelompok kontrol. Hasilnya seperti tampak pada Tabel 6.

Tabel 6. Hasil Analisis Uji Perbedaan Rerata antara Skor Pretes dan Postes Kemampuan Generik Sains (KGS) Siswa Kelompok Kontrol

\begin{tabular}{|c|c|c|c|c|c|}
\hline $\begin{array}{l}\text { Aspek } \\
\text { Kemampuan } \\
\text { Generik Sains } \\
\end{array}$ & $\begin{array}{l}\text { Rerata } \\
\text { Pretes } \\
(\%) \\
(2)\end{array}$ & $\begin{array}{c}\text { Rerata } \\
\text { Postes } \\
\text { (\%) } \\
\text { (3) }\end{array}$ & $\mid \begin{array}{c}\left|Z_{\text {hitung }}\right| \text { atau } \\
\left|t_{\text {hitung }}\right| \text { dan } p \\
\text { (4) }\end{array}$ & $\begin{array}{c}\mathrm{Z}_{\text {tabel }} \\
\text { atau } \\
\mathrm{t}_{\text {tabel }} \\
\text { (5) }\end{array}$ & $\begin{array}{l}\text { Ket.*) } \\
\text { (6) }\end{array}$ \\
\hline $\begin{array}{l}\text { 1. Mendeskripsikan } \\
\text { pengetahuan } \\
\text { fisika secara } \\
\text { efektif }\end{array}$ & 10,88 & 35,77 & $\begin{array}{c}\left|\mathrm{Z}_{\mathrm{hit}}\right|=7,695 \\
\mathrm{p}<0,05\end{array}$ & $\begin{array}{c}\mathrm{Z}_{\text {tab }} \\
=1,645\end{array}$ & $\begin{array}{l}\mathrm{H}_{\mathrm{o}} \\
\text { ditolak }\end{array}$ \\
\hline $\begin{array}{l}\text { 2. Mengintrpretasi- } \\
\text { kan konsep atau } \\
\text { prinsip dan } \\
\text { representasi } \\
\text { ilmiah } \\
\end{array}$ & 20,71 & 35,50 & $\begin{array}{c}\mathrm{t}_{\text {hit }}=10,812 \\
\mathrm{p}<0,05\end{array}$ & $\begin{array}{l}\mathrm{t}_{\mathrm{tab}}= \\
1,665\end{array}$ & $\begin{array}{l}\mathrm{H}_{\mathrm{o}} \\
\text { ditolak }\end{array}$ \\
\hline 3. Inferensi logika & 15,30 & 44,00 & $\begin{array}{c}\left|Z_{\text {hit }}\right|=7,017 \\
p<0,05\end{array}$ & $\begin{array}{c}\mathrm{Z}_{\mathrm{tab}} \\
=1,645\end{array}$ & $\begin{array}{l}\mathrm{H}_{\mathrm{o}} \\
\text { ditolak }\end{array}$ \\
\hline $\begin{array}{l}\text { 4. Menerapkan } \\
\text { konsep, } \\
\text { prinsip,atau } \\
\text { hukum } \\
\end{array}$ & 7,36 & 21,00 & $\begin{array}{c}\left|Z_{\text {hit }}\right|=7,301 \\
p<0,05\end{array}$ & $\begin{array}{c}\mathrm{Z}_{\mathrm{tab}} \\
=1,645\end{array}$ & $\begin{array}{l}\mathrm{H}_{\mathrm{o}} \\
\text { ditolak }\end{array}$ \\
\hline $\begin{array}{l}\text { Kemampuan } \\
\text { generik sains } \\
\text { secara umum } \\
\end{array}$ & 13,76 & 32,08 & $\begin{array}{c}\mathrm{t}_{\mathrm{hit}}=18,171 \\
\mathrm{p}<0,05\end{array}$ & $\begin{array}{l}\mathrm{t}_{\mathrm{tab}}= \\
1,665\end{array}$ & $\begin{array}{l}\mathrm{H}_{\mathrm{o}} \\
\text { ditolak }\end{array}$ \\
\hline
\end{tabular}

Keterangan*): $\mathrm{H}_{\mathrm{o}}$ ditolak jika $\left|\mathrm{Z}_{\text {hitung }}\right|$ atau $\left|\mathrm{t}_{\text {hitung }}\right|$ lebih besar dari $Z_{\text {tabel }}$ atau $t_{\text {tabel }}$
Tampak bahwa baik pada masing-masing aspek maupun secara keseluruhan menghasilkan nilai $\left|Z_{\text {hitung }}\right|=1,645$ dan $\left|t_{\text {hitung }}\right|=1,665$, yang berarti $H_{o}$ ditolak pada masing-masing aspek KGS maupun pada kemampuan KGS secara keseluruhan. Dengan demikian dapat dikatakan bahwa skor KGS siswa kelompok kontrol sesudah pembelajaran reguler secara signifikan lebih baik dari sebelum pembelajaran. Hal ini menunjukkan bahwa program pembelajaran fisika yang lazim digunakan guru juga dapat meningkatkan kemampuan generik sains siswa, baik pada masing-masing aspek generik maupun kemampuan generik sains secara keseluruhan. berikut ini:

Secara diagram batang dapat digambarkan seperti

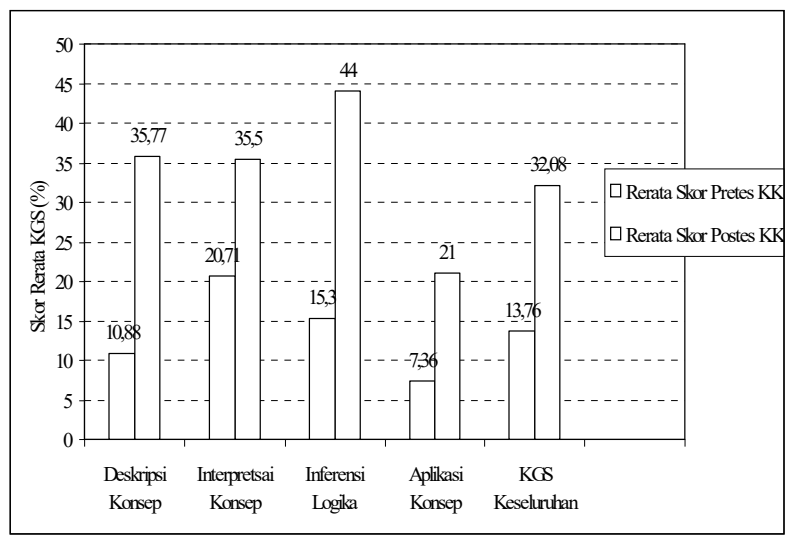

Gambar 2. Perbedaan Rerata antara Skor Pretes dan Postes KGS Siswa Kelompok Kontrol

\section{Menguji Efektivitas Pembelajaran Fisika Berbasis IT2PK}

Sebagaimana diungkapkan di atas bahwa baik pembelajaran melalui program yang dikembangkan maupun melalui pembelajaran reguler, keduanya samasama memperlihatkan adanya peningkatan skor KGS yang signifikan. Akan tetapi perlu ditinjau program pembelajaran manakah yang lebih baik dalam hal meningkatkan kemampuan tersebut. Untuk itulah dilakukan uji perbedaan rerata skor $n$-gain KGS antara siswa kelompok eksperimen dan kelompok kontrol. Hasilnya seperti tampak pada Tabel 7 berikut ini. 
J. Pijar MIPA, Vol. VI No.2, September : 49 - 55

Tabel 7. Hasil Analisis Uji Perbedaan Rerata Skor N-Gain KGS antara Siswa

Kelompok Eksperimen dan Kelompok Kontrol

\begin{tabular}{|c|c|c|c|c|c|}
\hline \multirow[b]{2}{*}{$\begin{array}{c}\text { Aspek Kemampuan Generik Sains } \\
\text { (1) }\end{array}$} & \multicolumn{2}{|c|}{ Rerata $N$-Gain } & \multirow{2}{*}{$\begin{array}{c}\text { Nilai } t_{\text {hitung }} \\
\text { (4) }\end{array}$} & \multirow{2}{*}{$\begin{array}{c}\text { Nilai } t_{\text {tabel }} \\
(\alpha=0,05) \\
\text { (5) }\end{array}$} & \multirow{2}{*}{$\begin{array}{c}\text { Ket. *) } \\
(\mathbf{6})\end{array}$} \\
\hline & $\begin{aligned} \mathrm{KE} \\
(2)\end{aligned}$ & $\begin{array}{l}\text { KK } \\
(3)\end{array}$ & & & \\
\hline $\begin{array}{l}\text { 1. Mendeskripsikan pengetahuan } \\
\text { fisika secara efektif }\end{array}$ & 0,50 & 0,28 & $\begin{aligned} & \mathrm{t}_{\text {hit }}=15,828 \\
& \mathrm{p}<0,05\end{aligned}$ & $\mathrm{t}_{\mathrm{tab}}=1,665$ & $\begin{array}{c}\mathrm{H}_{\mathrm{o}} \\
\text { ditolak }\end{array}$ \\
\hline $\begin{array}{l}\text { 2. Menginterpretasikan konsep atau } \\
\text { prinsip dan representasi ilmiah }\end{array}$ & 0,53 & 0,18 & $\begin{aligned} & \mathrm{t}_{\text {hit }}=20,657 \\
& \mathrm{p}<0,05\end{aligned}$ & $\mathrm{t}_{\mathrm{tab}}=1,665$ & $\begin{array}{c}\mathrm{H}_{\mathrm{o}} \\
\text { ditolak }\end{array}$ \\
\hline 3. Inferensi logika & 0,45 & 0,32 & $\begin{aligned} \mathrm{t}_{\mathrm{hit}} & =9,220 \\
\mathrm{p} & <0,05\end{aligned}$ & $\mathrm{t}_{\mathrm{tab}}=1,665$ & $\begin{array}{c}\mathrm{H}_{\mathrm{o}} \\
\text { ditolak }\end{array}$ \\
\hline $\begin{array}{l}\text { 4. Menerapkan konsep, prinsip,atau } \\
\text { hukum }\end{array}$ & 0,52 & 0,15 & $\begin{aligned} & \mathrm{t}_{\text {hit }}=27,274 \\
& \mathrm{p}<0,05\end{aligned}$ & $t_{\text {tab }}=1,665$ & $\begin{array}{c}\mathrm{H}_{\mathrm{o}} \\
\text { ditolak }\end{array}$ \\
\hline $\begin{array}{l}\text { Kemampuan generik sains secara } \\
\text { umum }\end{array}$ & 0,64 & 0,21 & $\begin{aligned} & \mathrm{t}_{\text {hit }}=26,877 \\
& \mathrm{p}<0,05\end{aligned}$ & $\mathrm{t}_{\mathrm{tab}}=1,665$ & $\begin{array}{c}\mathrm{H}_{\mathrm{o}} \\
\text { ditolak }\end{array}$ \\
\hline
\end{tabular}

Catatan *): $\mathrm{H}_{\mathrm{o}}$ ditolak jika $\left|\mathrm{Z}_{\text {hitung }}\right|=1,645$ dan $\left|\mathrm{t}_{\text {hitung }}\right|=1,665$, atau $\mathrm{p}=0,05$.

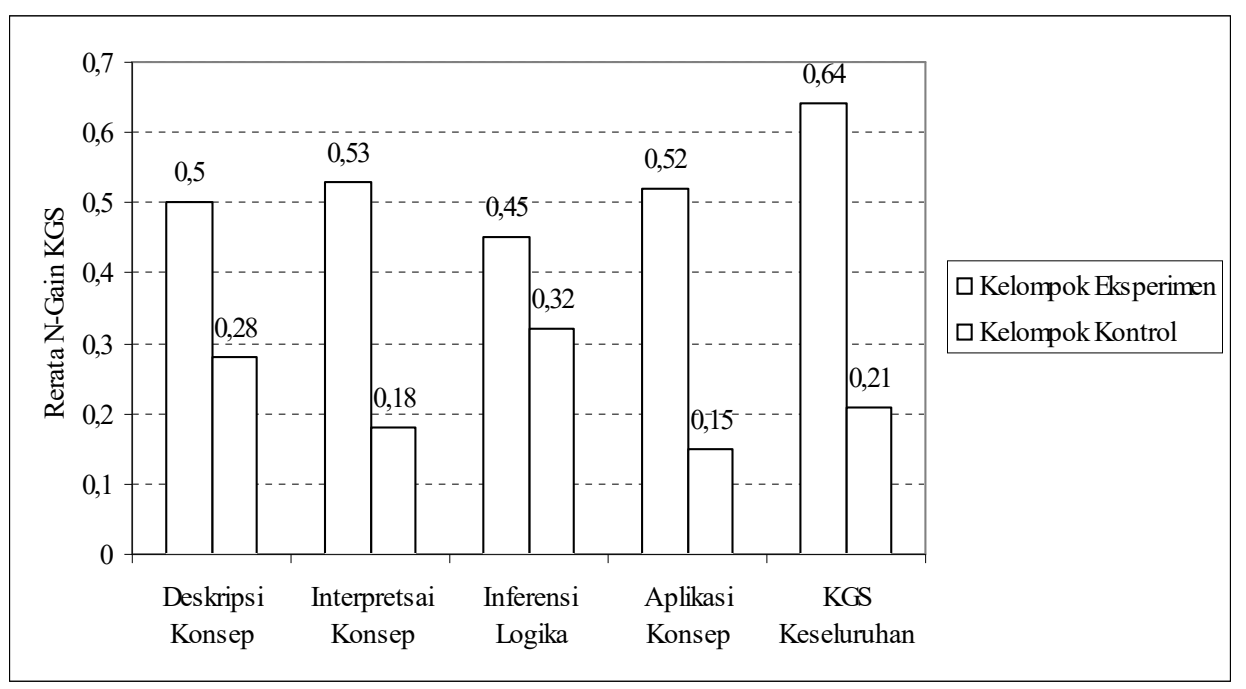

Gambar 3. Perbedaan Rerata Skor $N$-Gain KGS antara Siswa Kelompok Eksperimen dan Siswa Kelompok Kontrol

Dari Tabel 7, tampak bahwa baik pada setiap aspek maupun pada KGS secara umum, menghasilkan nilai nilai Àt $t_{\text {hitung }}$ $̀$ e" 1,665 , berarti $H_{0}$ ditolak pada masingmasing aspek kemampuan maupun pada KGS secara umum. Dengan demikian dapat dikatakan bahwa peningkatan perolehan skor KGS siswa kelompok eksperimen secara signifikan lebih baik dari siswa kelompok kontrol. Dengan kata lain dapatlah disimpulkan bahwa program pembelajaran yang dikembangkan secara signifikan lebih efektif dari program pembelajaran reguler dalam hal meningkatkan kemampuan generik sains siswa.

Berdasarkan hasil observasi langsung tentang keterlaksanaan program pembelajaran yang diterapkan, didapatkan suatu kondisi bahwa secara umum siswa cukup senang dengan kegiatan-kegiatan dan latihan-latihan untuk memperdalam kemampuan generik sains melalui kegiatan remidial dan pengayaan. Pengembalian dengan segera tugas-tugas yang telah dikoreksi oleh guru juga sangat disenangi oleh siswa. Mereka selalu ingin mengetahui hasil dari pekarjaan yang telah dia kerjakan. Hal ini perlu dipertahankan dan ditingkatkan karena kebiasaan seperti

ini dipercaya dapat meningkatkan motivasi belajar siswa [10]. Guru harus mengupayakan untuk selalu meluangkan waktunya mengoreksi setiap tugas yang diberikan kepada siswanya.

Permasalahan alokasi waktu menjadi kendala sehubungan dengan pelaksanaan kegiatan laboratorium di sekolah. Hal ini harus disiasati sedemikian rupa agar kegiatan dapat terlaksana sesuai dengan waktu yang tersedia. Misalnya saja siswa diminta membuat persiapanpersiapan terlebih dahulu sebelum melaksanakan kegiatan, seperti membuat tabel-tabel pengamatan ataupun kerangka- kerangka grafik yang dibutuhkan dalam pengamatan, hal ini dapat dipersiapkan terlebih dahulu dari rumah agar tidak menyita banyak waktu pada saat melakukan kegiatan di sekolah. Sebagai konsekuensinya materi kegiatan laboratorium harus diberikan jauh-jauh hari agar siswa mengetahui hal apa saja yang harus mereka persiapkan.

Sehubungan dengan proses pembelajaran, pada kegiatan pembelajaran tentang definisi gerak benda, penekanan pemahaman tentang titik acuan perlu dilakukan 
Program Pembelajaran Fisika Berbasis Inkuiri Terbimbing ..... (Marzuki dan Hinduan)

melalui pemberian contoh-contoh, karena hal ini menjadi dasar pijakan untuk memahami definisi tentang gerak benda.

Pemahaman tentang konsep kelajuan dan kecepatan harus dimulai dengan pemahaman yang mendalam tentang pengertian jarak tempuh dan perpindahan. Beberapa contoh yang mendukung pemahaman siswa untuk bisa membedakan dengan jelas antara jarak tempuh dan perpindahan hendaknya disediakan secukupnya. Mengingat kemampuan membuat skala menjadi salah satu aspek penilaian dalam penelitian ini, maka guru juga harus memperhatikan hal ini terutama pada waktu membuat garis yang mewakili besar suatu besaran, jangan sampai melukis garis yang mewakili jarak $20 \mathrm{~km}$ misalnya dibuat lebih panjang dari garis yang mewakili jarak $30 \mathrm{~km}$. Kesalahan semacam ini sering dilakukan oleh guru-guru di sekolah.

Setelah siswa memahami dengan cukup baik tentang perbedaan jarak tempuh dan perpindahan maka tidaklah terlalu sulit untuk membimbing mereka memahami tentang konsep kelajuan dan kecepatan serta mendefinisikan sendiri secara operasional. Pemberian contoh-contoh harus lebih diintensifkan agar siswa mampu mengaplikasikannya pada berbagai contoh yang lainnya. Kemampuan mengaplikasikan konsep atau prinsip pada kasus-kasus sederhana lainnya merupakan salah satu aspek penilaian dalam penelitian ini.

Perlu dilakukan latihan secara lebih intensif tentang membuat grafik serta menginterpretasi grafik ataupun tabel dengan waktu yang khusus, mengingat kebanyakan siswa memiliki kesulitan dalam kasus ini. Kemampuan ini sangat penting untuk pengembangan imu pengetahuan selanjutnya.

\section{KESIMPULAN DAN SARAN}

Berdasarkan hasil analisis data dan pembahasan seperti dikemukakan di atas, dapatlah disimpulkan sebagai berikut: (1) kualitas kemampuan generik sains siswa setelah melalui pembelajaran berbasis IT2PK secara umum dalam kategori baik, dengan peningkatan skor dalam kualitas sedang; (2) Program Pembelajaran Fisika berbasis IT2PK dapat meningkatkan kemampuan generik sains siswa secara signifikan; dan (3) uji perbedaan rerata terhadap skor $n$-gain antara siswa kelompok eksperimen dan kelompok kontrol memberikan kesimpulan bahwa Program Pembelajaran Fisika berbasis IT2PK secara signifikan lebih efektif dari pembelajaran reguler dalam hal meningkatkan kemampuan generik sains siswa.

Penelitian ini masih terbatas pada aspek-aspek kemampuan generik sains yang teridentifikasi dari pokok bahasan mengenai topik gerak lurus saja. Disarankan bagi para pembaca untuk mencoba melakukan penelitian serupa pada aspek-aspek KGS yang lebih lengkap melalui topik yang lebih luas serta pada jenjang pendidikan yang lebih tinggi.

\section{DAFTAR PUSTAKA}

[1] Hinduan, A.A. (2003). "Meningkatkan Kualitas SDM Melalui Pendidikan IPA". Makalah disajikan dalam Seminar Himpunan Sarjana Pendidikan Ilmu Pengetahuan Alam Indonesia yang Diadakan di Bandung tanggal $1-2$ Agustus 2003.

[2] Slavin, R.E. (1995). Cooverative Learning. Second Edition. Boston:Allyn and Bacon.

[3] McDermott, L. C. (1990). “A Perspective on Teacher Preparation in Physics and Other Sciences: The need for Special Science Courses for teachers". American Journal of Physics. 58(8).

[4] Rutherford, J. F. \& Ahlgren, A. (1990). Science for All American. New York: Oxford University Press.

[5] Reif, F. (1995). "Millikan Lecture 1994: Understanding and Teaching Important Scientific Thought Processes". American Journal of Physics. 63 (1).

[6] Suprapto, B. (2000). Hakikat Pembelajaran MIPA \& Kiat Pembelajaran Fisika di Perguruan Tinggi. Proyek Pengembangan Universitas Terbuka Direktorat Jenderal Pendidikan Tinggi Departemen Pendidikan Nasional.

[7] Suma, K. (2003). Pembekalan KemampuanKemampuan Fisika Bagi Calon Guru. Disertasi Doktor pada PPS UPI Bandung: tidak diterbitkan.

[8] Marzuki (2010). "Identifikasi Aspek-Aspek Kemampuan Generik Sains yang Dapat Dikembangkan Melalui Pembelajaran Fisika". Makalah disajikan pada Seminar Internasional: Practice Pedagogic in Global Education Perspective, UPI Bandung 17th Mey 2010.

[9] Ruseffendi, H.E.T.. (2001). Dasar-Dasar Penelitian Pendidikan dan Bidang Non- Eksakta Lainnya. Semarang: IKIP Semarang Press.

[10] Sumaji. (2003). Pendidikan Sains yang Humanistis. Kanisius: Yogyakarta. 